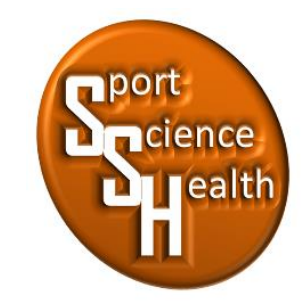

ISSN 2715-3886

\title{
Pengembangan Model Pembelajaran Kebugaran Jasmani Dengan Modifikasi Permainan Pada Siswa Kelas VIII
}

\author{
Gagah Andika Nanda Prayoga ${ }^{1 \star}$, Febrita Paulina Heynoek ${ }^{2}$, Dona Sandy Yudasamara ${ }^{3}$ \\ 1,2,3 Jurusan Pendidikan Jasmani, Kesehatan dan Rekreasi, Fakultas IImu Keolahragaan, \\ Universitas Negeri Malang, Jalan Semarang No 5, Malang, Jawa Timur, 65145, Indonesia \\ *Penulis koresponden: gagah.021296@gmail.com, 089627168924
}

Artikel diterima: 9 Januari 2020; direvisi: 16 Oktober 2020; disetujui: 22 Oktober 2020

\begin{abstract}
The purpose of this study is to develop a physical fitness learning model using game modifications for the eighth grade students of SMP Negeri 3 Panarukan which is expected to be used as a means of supporting teachers in providing physical fitness subjects. This research uses the type of research \& development (R\&D) development with qualitative and quantitative data analysis techniques with percentages. The result of this research is physical fitness learning model using game modification for VIII grade students of SMP Negeri 3 Panarukan.
\end{abstract}

Keyword: physical fitness learning, game modification, learning modell

\begin{abstract}
Abstrak: Tujuan penelitian ini untuk mengembangkan model pembelajaran kebugaran jasmani dengan menggunakan modifikasi permainan pada siswa kelas VIII SMP Negeri 3 Panarukan diharapkan dapat dijadikan sebagai sarana pendukung guru dalam memberikan mata pelajaran kebugaran jasmani. Penelitian menggunakan jenis pengembangan research \& development (R\&D) dengan teknik analisis data kualitatif dan kuantitatif dengan persentase. Hasil penelitian ini yaitu model pembelajaran kebugaran jasmani dengan menggunakan modifikasi permainan pada siswa kelas VIII SMP Negeri 3 Panarukan.
\end{abstract}

Kata kunci: pembelajaran kebugaran jasmani, modifikasi permainan, modell pembelajaran

\begin{abstract}
PENDAHULUAN
Pendidikan jasmani merupakan pendidikan yang mempunyai fungsi mendidik melalui gerak jasmani. Pendidikan jasmani juga dapat menggali potensi yang ada pada seorang anak melalui aktivitas gerak jasmani. Secara tidak sadar gerak jasmani dilakukan pada kegiatan sehari-hari. Menurut Kwon \& Block (2017) pendidikan jasmani merupakan media untuk mendorong perkembangan keterampilan motorik, kemampuan fisik, pengetahuan penalaran, penghayatan nilai (sikap, mental, emosional, spiritual, sosial), dan pembiasaan pola hidup sehat yang bermuara untuk merangsang pertumbuhan serta perkembangan yang seimbang. Menurut ahli mengatakan bahwa pendidikan jasmani adalah proses pendidikan yang memanfaatkan aktifitas fisik untuk mengembangakan potensi perserta didik dalam hal psikomotor, kognitif, dan afektif (Coulter \& Ní Chróinín, 2013; Environment;, Committee on Physical Activity and Physical Education in the School Environemnt \& Food and Nutrition Board; Institute of Medicine, 2013; Lonsdale et al., 2013; Metzler, 2017;
\end{abstract}


Meyer et al., 2013; Smith, Monnat, \& Lounsbery, 2015). Jadi dari beberapa pendapat di atas dapat disimpulkan bahwa pendidikan jasmani adalah proses pendidikan yang memanfaatkan gerak jasmani yaitu permainan dan olahraga, untuk mengembangakan fisik, mental dan emosional serta juga mengembangkan potensi psikomotor, kognitif, dan afektif dalam mencapai tujuan pembelajaran.

Tujuan dari pendidikan jasmani, olahraga, dan kesehatan yaitu untuk, membentuk karakter yang kuat, mengembangkan keterampilan gerak seseorang, menumbuhkan kemampuan berfikir secara kritis, mengembangkan sikap sportifitas, serta pola hidup yang sehat (Association for Physical Education, 2020; Bailey, 2013). Menurut López-Pastor, Kirk, Lorente-Catalán, MacPhail, \& Macdonald (2013) tujuan pendidikan jasmani yaitu memberikan kesempatan pada anak untuk mempelajari berbagai kegiatan yang membina sekaligus mengembangkan potensi anak, baik dalam aspek fisik, mental, sosial, emosional dan moral. Dalam pembelajaran guru pendidikan jasmani harus mencapai tujuan dari pendidikan jasmai dengan mengajarkan gerak jasmani. Oleh karena itu pembelajaran pendidikan jasmani sangatlah dibutuhkan untuk mengembangkan potensi siswa dengan melibatkan gerak fisik yaitu mengembangkan gerak fisik yg melibatkan keterampilan gerak untuk merangsang nalar dan pengetahuan siswa.

Pendidikan jasmani adalah salah satu mata pelajaran yang wajib di tempuh oleh lingkungan sekolah tingkat Sekolah Dasar (SD), Sekolah Menengah Pertama (SMP), dan Sekolah Menengah Atas (SMA) untuk melatih dan mengembangakan kebiasaan fisik dan mental siswa. Kebugaran jasmani merupakan salah satu materi yang ada dalam pendidikan jasmani pada jenjang SMP. Kebugaran jasmani atau kesegaran jasmani ini merupakan salah satu materi yang ada dalam mata pelajaran pendidikan jasmani, olahraga, dan kesehatan sesuai kurikulum kelas VIII.

Pembelajaran pendidikan jasmani menggunakan gerak fisik untuk merangsang perkembangan kemampuan kesegaran jasmani siswa. Menurut Voss et al. (2016)kebugaran jasmani adalah kemampuan tubuh untuk melakukan sesuatu pekerjaan fisik yang dikerjakan sehari-hari tanpa menimbulkan kelelahan yang berarti. Kebugaran jasmani adalah derajat sehat dinamis seseorang yang menjadi kemampuan jasmani dasar untuk dapat melaksanakan tugas yang harus dilaksanakan (Gray et al., 2015; Saunders et al., 2016). Dari pendapat di atas dapat disimpulkan bahwa kebugaran jasmani adalah kemampuan dan keadaan sehat jasmani seseorang dalam melakukan aktivitas fisik sehari-hari tanpa merasakan kelelahan yang berarti serta memiliki cadangan energi untuk keperluan lain dalam waktu senggangnya.

Orang yang sehat belum tentu bugar, tetapi orang yang bugar sudah pasti sehat. Dalam pendidikan jasmani materi kebugaran jasmani sangatlah penting di berikan kepada siswa, karena secara tidak sadar dalam pembelajaran pendidikan jasmani, olahraga, dan kesehatan di sekolah siswa melakukan aktivitas gerak kebugaran jasmani pada tubuh secara tidak langsung meningkat sehingga tubuh tetap sehat dan bugar. Menurut (Fikri, 2017) Terjadi peningkatan kebugaran jasmani siswa kelas X di SMA Negeri 1 Lubuklinggau setelah mengikuti pembelajaran menggunakan metode latihan sirkuit selama dua siklus, walaupun belum semua siswa berhasil memperoleh kategori baik sekali, tapi sebagian besar siswa mencapai kateori baik.

Sekolah harus menerapkan mata pelajaran yang sesuai dengan kompetensi inti dan kompetensi dasar yang ada dalam pengembangan kurikulum terbaru. Menurut Alawiyah (2015) Sistem Pendidikan Nasional menyebutkan bahwa kurikulum adalah seperangkat rencana dan pengaturan mengenai tujuan, isi, dan bahan pelajaran, serta cara yang digunakan sebagai pedoman penyelenggaraan kegiatan pembelajaran untuk mencapai tujuan pendidikan tertentu.

Adapun kompetensi inti dan kompetensi dasar pada materi kebugaran jasmani kelas VIII Sekolah Menengah Pertama adalah sebagai tabel 1 berikut: 
Tabel 1 Kompetensi inti dan kompetensi dasar kelas VIII (Permendikbud, 2016:3-4)

\begin{tabular}{lllr}
\hline Kompetensi inti & Kompetensi dasar \\
\hline 3. Memahami dan menerapkan & 3.5 Memahami konsep latihan \\
pengetahuan (faktual, konseptual, dan & peningkatan derajat kebugaran jasmani \\
prosedural) berdasarkan rasa ingin & yang terkait dengan keterampilan \\
tahunya tentang ilmu pengetahuan, & (kecepatan, kelincahan, keseimbangan, \\
teknologi, seni, budaya terkait fenomena & dan koordinasi) serta pengukuran \\
dan kejadian tampak mata. & hasilnya. & \\
4. Mengolah, menyaji, dan menalar & 4.5 Mempraktikkan latihan peningkatan \\
dalam ranah konkret (menggunakan, & derajat kebugaran jasmani yang terkait \\
mengurai, merangkai, memodifikasi, dan & dengan keterampilan (kecepatan, \\
membuat) dan ranah abstrak (menulis, kelincahan, keseimbangan, dan & \\
membaca, menghitung, menggambar, koordinasi) serta pengukuran hasilnya. \\
dan mengarang) sesuai dengan yang & & \\
dipelajari di sekolah dan sumber lain & & \\
yang sama dalam sudut pandang/teori. &
\end{tabular}

Berdasarkan paparan kompetensi inti dan kompetensi dasar di atas, dalam proses pembelajaran pendidikan jasmani peran guru sangatlah penting. Dalam proses pembelajaran khususnya materi kebugaran jasmani guru pendidikan jasmani harus lebih kreatif dalam memilih model pembelajaran yang cocok untuk siswa.

Model pembelajaran dengan modifikasi permainan adalah alternatif untuk mendorong minat siswa dalam proses pembelajaran. Dengan modifikasi permainan siswa akan belajar dengan senang karena tidak ada peraturan yang ketat dan dalam melakukan aktivitas tidak ada paksaan. Menurut Alaunyte, Stojceska, \& Plunkett (2015) modifikasi secara umum di artikan sebagai usaha untuk mengubah atau menyesuaikan. Namun secara khusus modifikasi adalah suatu upaya yang dilakukan untuk menciptakan dan menampilkan sesuatau yang baru, unik, dan menarik. Modifikasi pembelajaran adalah solusi efektif atas permasalahan dalam pembelajaran dalam pendidikan jasmani.

Berdasarkan dari observasi awal pada tanggal 26 Februari 2019 pengamatan peneliti melakukan analisis kebutuhan melalui wawancara pada guru pendidikan jasmani dan penyebaran angket kepada siswa SMP Negeri 3 Panarukan. Dari hasil wawancara kepada guru pengajar pendidikan jasmani kelas VIII SMP Negeri 3 Panarukan mengatakan bahwa memberi pengajaran kebugaran jasmani dengan komponen (kecepatan, kelincahan,dan keseimbangan). Dalam pembelajaran kebugaran jasmani guru pernah menggunakan modifikasi permainan, tetapi antusias, keseriusan dan ketertarikan siswa dalam pembelajaran kebugaran jasmani berkurang dibandingkan pembelajaran bola besar misalnya. Berkisar $40 \%$ siswa yang kurang antusias dalam pembelajaran kebugaran jasmani.

Dari penyebaran angket yang diajukan kepada 29 siswa kelas VIII SMP Negeri 3 Panarukan diperoleh hasil: 1) 9 siswa (31\%) menyatakan sering menerima pelajaran materi kebugaran jasmani dan 20 siswa (69\%) menyatakan pernah menerima pelajaran materi kebugaran jasmani, 2) 13 siswa (44,8\%) menjawab dua kali pertemuan dan 16 siswa $(55,2 \%)$ menjawab satu kali pertemuan materi kebugaran jasmani diberikan, 3) 3 siswa (10,3\%) menjawab tiga jam, 24 siswa (82,7\%) menjawab dua jam, dan 2 siswa $(6,8 \%)$ menjawab 1 jam pelajaran tiap satu kali pertemuan materi kebugaran jasmani di berikan, 4) 29 siswa (100\%) menjawab materi koordinasi tidak diberikan, 5) 29 siswa (100\%) menjawab perlu materi kebugaran jasmani di berikan, 6) 3 siswa $(10,3 \%)$ menjawab sangat sering, 10 siswa $(34,4 \%)$ menjawab sering, dan 16 siswa $(55,1)$ menjawab pernah melakukan pembelajaran kebugaran jasmani. Dari jawaban siswa di atas menyatakan siswa telah menerima materi kebugaran jasmani dan hanya unsur kebugaran jasmani koordinasi yang belum mereka terima.

Berikut lanjutan angket di atas: 7) 5 siswa (17,2\%) menjawab sangat baik, 21 siswa $(72,4 \%)$ menjawab baik, 3 siswa (10,3\%) menjawab cukup kemampuan dalam kebugaran jasmani bahwa, 8) 26 siswa (89,6\%) menjawab sangat setuju, 3 siswa $(10,3)$ menjawab setuju pembelajaran kebugaran jasmani dilaksanakan di sekolah, 9) 26 siswa (100\%) menjawab fungsi dari pembelajaran kebugaran jasmani untuk meningkatkan kebugaran, 10) 11 siswa (38\%) menjawab sangat menarik, 18 siswa (62\%) menjawab menarik pada pembelajaran kebugaran jasmani,11) 27 siswa $(93,2 \%)$ menjawab dalam bentuk permainan, 2 siswa $(6,8 \%)$ 
menjawab dalam bentuk materi dalam pembelajaran kebugaran jasmani, 12) 8 siswa $(27,6 \%)$ menjawab sangat perlu, 20 siswa (69\%) menjawab perlu, 1 siswa $(3,4 \%)$ menjawab tidak perlu modifikasi dalam pembelajaran kebugaran jasmani, 13) 21 siswa $(72,4 \%)$ menjawab video pembelajaran, 8 siswa $(27,6 \%)$ menjawab dalam bentuk buku media yang memudahkan mereka belajar dalam pembelajaran kebugaran jasmani.

Dari hasil observasi yang telah dipaparkan di atas dapat disimpulkan bahwa analisis kebutuhan guru pendidikan jasmani dan siswa kelas VIII SMP Negeri 3 Panarukan membutuhkan bentuk model pembelajaran yang baru yaitu, modifikasi permainan dikarenakan antusias, keseriusan dan ketertarikan siswa dalam pembelajaran kebugaran jasmani masih kurang. Mengingat tujuan dari modifikasi yaitu memberi solusi untuk permasalan dalam pembelajaran. Bagi guru pendidikan jasmani, dapat menjadi tambahan referensi baru untuk model pembelajaran kebugaran jasmani. Sedangkan bagi siswa kelas VIII SMP Negeri 3 Panarukan dapat menjadi alternatif baru sebagai media pembelajaran baru yang dapat meningkatkan keaktifan, antusias, dan meningkatkan kebugaran pada tubuh siswa.

Pembelajaran menggunakan modifikasi permainan dapat mendorong siswa menjadi lebih aktif, antusias, dan menyenangkan sehingga pembelajaran menjadi lebih menarik dan guru mudah dalam dalam menyampaikan materi. Hal tersebut akan membuat pembelajaran kebugaran jasmani lebih efektif. Pada pembelajaran pendidikan jasmani materi kebugaran jasmani di SMP Negeri 3 Panarukan pernah menggunakan metode modifikasi permainan tetapi pengaruhnya belum banyak terhadap antusias siswa, maka peneliti akan mengembangkan model pembelajaran modifikasi permainan dalam materi kebugaran jasmani yang mengandung empat komponen kebugaran jasmani.

Pada penelitian terdahulu oleh Cahyani, (2016) dihasilkan produk berupa: 1) produk terdiri dari 8 model permainan yaitu permainan barisan bebelok, kardus berloncat, permainan bola api, permainan bola kertas berkarung, perainan kertas balap, permainan balap balon, permainan bola terowongan, dan permainan beralih penyeberangan, 2) subjek dilakukan pada siswa SMK kelas X, 3) pengembangan model permainan dikemas dalam bentuk buku panduan. Penelitian tersebut juga selaras dengan penelitian Reza, (2013) yang dihasilkan produk berupa: 1) model bermain pos kekuatan dam model bermain pos kecepatan yang masing-masing terdiri dari 4 macam model bermain, 2) subjek diterapkan pada siswa kelas V SD, 3) produk dikemas dalam buku panduan dan RPP. Penelitian yang selaras oleh Muzakki, (2014) dihasilkan produk berupa: 1) produk berupa materi pengembangan latihan kesegaran jasmani menggunakan metode tebak dadu, 2) subjek diterapkan pada siswa kelas V SD, 3) produk dikemas dalam bentuk buku materi latihan kesegaran jasmani menggunakan metode tebak dadu. Dari penelitian terdahulu di atas, peneliti tertarik mengembangkan modifikasi permainan dengan 4 unsur kebugaran jasmani yang telah ditentukan berdasarkan kompetensi inti dan kompetensi dasar pada siswa kelas VIII yang akan dikemas dalam bentuk video. Yang mana dalam paparan penelitian terdahulu di atas modifikasi permainan belum dikembangkan pada siswa kelas VIII.

Adapun beberapa penelitian terdahulu yang mendukung penelitian ini Kurniawan \& Hidayat, (2015) "Berdasarkan hasil penelitian tentang pengaruh modifikasi permainan bola voli terhadap kerjasama siswa pada pembelajaran penjasorkes, diketahui bahwa modifikasi permainan bola voli dapat meningkatkan kerjasama siswa pada mengikuti pembelajaran penjasorkes". Hermansah, (2018) "modifikasi permainan bola tangan terhadap hasil belajar passing bola tangan berpengaruh dalam pembelajaran bola tangan mahasiswa semester IV tahun akademik 2017/2018". Lestari, (2015) Lestari "ada pengaruh yang signifikan penerapan modifikasi permainan terhadap hasil belajar passing bawah bola voli pada siswa kelas VIII SMP Negeri 4 Pasuruan". Berdasarkan penelitian terdahulu di atas hasil dari modifikasi pembelajaran sangatlah berpengaruh terhadap kemampuan maupun minat siswa dalam belajar. Maka peneliti dalam hal ini akan mengembangkan modifikasi pembelajaran untuk pembelajaran kebugaran jasmani. Selain dari sisi hasilnya, peneliti juga akan mengembangkan pengembangan modifikasi pembelajaran pada kebugaran jasmani. Mengingat belum ada pengembangan modifikasi permainan dalam kebugaran jasmani pada siswa kelas VIII.

Dari uraian di atas, maka penelitian yang akan dilakukan peneliti berjudul "Pengembangan Model Pembelajaran Kebugaran Jasmani Dengan Modifikasi Permainan Pada Siswa Kelas VIII SMP Negeri 3 Panarukan Kabupaten Situbondo".

mengembangkan model pembelajaran kebugaran jasmani dengan menggunakan modifikasi permainan pada siswa kelas VIII SMP Negeri 3 Panarukan diharapkan dapat mempermudah siswa untuk memahami konsep 
dari pembelajaran kebugaran jasmani dan siswa cenderung lebih menyukai pembelajaran kebugaran jasmani, siswa tidak merasa bosan saat mengikuti pembelajaran dan tingkat kebugaran tubuhnya meningkat.

\section{METODE}

Pada pengembangan model pembelajaran kebugaran jasmani dengan modifikasi permainan pada siswa kelas VIII SMP Negeri 3 Panarukan harus mengikuti langkah-langkah atau prosedur pengembangan produk dalam penelitian pengembangan. Jadi penelitian dan pengembangan ini, menggunakan model prosedural. Model prosedural ialah model yang menggariskan langkah-langkah atau prosedur yang harus diikuti untuk menghasilkan produk dan persifat deskriptif (Tight, Symonds, \& Symonds, 2016).

Pada penelitian ini peneliti menggunakan model pengembangan dari Tight, Symonds, \& Symonds (2016) yaitu:(1) Melakukan penelitian dan pengumpulan informasi (kajian pustaka, pengamatan kelas, persiapan laporan tentang pokok persoalan), (2) melakukan perencanaan (pendefinisian keterampilan, rumusan tujuan, penentuan urutan pengajaran, dan uji coba kelas kecil), (3) mengembangkan produk awal (penyiapan materi pengajaran, penyusunan buku pegangan, dan perlengkapan evaluasi), (4) melakukan uji lapangan permulaan (dilakukan dalam 1-3 sekolah menggunakan 6-12 subjek), (5) melakukan revisi terhadap produk utama (sesuai dengan saran -saran dari hasil uji lapangan permulaan), (6) melakukan uji lapangan utama (dangan 5-15 sekolah dengan 30-100 subjek), (7) melakukan revisi produk (berdasarkan saran-saran dari hasil uji coba lapangan utama), (8) uji lapangan meliputi 10- 30 sekolah dengan 40-200 subjek, (9) revisi produk akhir, (10) membuat laporan mengenai produk pada jurnal, bekerja dengan penerbit yang dapat melakukan distribusi secara komersial.

Pada penelitian pengembangan tidak harus menggunakan 10 langkah-langkah yang tercantum. Peneliti dapat memodifikasi langkah-langkah yang ada dan memilih langkah-langkah paling tepat berdasarkan kondisi khusus yang dihadapinya dalam proses pengembangan (Leguina, 2015; Van Hoecke, 2016).

Dari pernyataan di atas peneliti mengambil 7 langkah-langkah yang tercantum dalam langkah-langkah yang dikemukakan, berdasarkan kebutuhan peneliti dalam pengembangan yang akan ditelti, berikut langkahlangkah pengembangan model pembelajaran kebugaran jasmani dengan modifikasi permainan pada siswa kelas VIII SMP Negeri 3 Panarukan.

Melakukan penelitian awal dengan melakukan wawancara dan penyebaran angket, Mengembangkan produk awal, Evaluasi produk oleh para ahli, Uji coba kelompok kecil, Revisi produk awal sesuai dari uji coba kelompok kecil, Uji coba kelompok besar, Revisi produk akhir sesuai dari uji coba kelompok besar.

Pada penelitian ini menggunakan jenis data kualitatif dan kuantitatif. Data kuantitatif dari penelitian awal yaitu penyebaran angket kepada siswa kelas VIII SMP Ngeri 3 Panarukan yang berjumlah 26 siswa, dari uji coba lelompok yaitu uji coba kelompok kecil dan uji coba kelompok besar. Sedangkan data kuantitatif dari wawancara guru pengajar dan masukan dan saran oleh 1 ahli pembelajaran, 1 ahli modifikasi permainan, dan 1 ahli media.

Pada instrumen pengumpulan data penelitian ini menggunakan Kuesioner dan wawancara. Kueisioner diberikan pada siswa kelas VIII SMP Negeri 3 Panarukan. Kuesioner adalah beberapa pertanyaan tertulis yang digunakan untuk memperoleh infomasi dari responden tentang apa yang akan diteliti (Sekaran \& Bougie, 2014). Kuesioner untuk siswa berupa kuesioner tertutup. Sedangkan kuesioner untuk para ahli berupa kuesioner tertutup yang disertai saran. Kuesioner tertutup ialah, kuesioner yang sudah disediakan jawabannya (Schulz, 2013). Wawancara dilakukan pada guru pengajar, 1 ahli pembelajaran, dan 1 ahli modifikasi permainan.

Penelitian ini menggunakan teknik analisis data yaitu teknik analisis kualitatif dan kuantitatif. Menurut Laing (2015) analisis data kualitatif dan kuantitatif ialah analisis data kualitatif data yang diperoleh dalam bentuk uraian yang tidak dapat diubah dalam bentuk angka dan analisis data kuantitatif data yang dikumpulkan dapat diklarifikasi dalam bentuk angka dan kategori.

Analisis data kualitatif digunakan untuk menganalisis dari hasil pengumpulan data masukan dan tanggapan tentang rancangan produk melalui wawancara yang ditarik kesimpulan demi kesempurnaan produk. Sedangkan analisis kuantitatif digunanan untuk menganalisis dari hasil pengumpulan data penelitian awal, uji coba kelompok kecil, dan uji coba kelompok besar. 
Untuk mengolah data yang deskriptif persentase menggunakan rumus Taherdoost (2018) ialah sebagai berikut:

$$
P=\frac{f}{N} \times 100 \%
$$

Keterangan:

$\mathrm{P} \quad=$ hasil persentase evaluasi uji coba

$\mathrm{F} \quad=$ persentase yang dicari

$\mathrm{N} \quad=$ jumlah frekuensi

Kriteria untuk menentukan kesimpulan dari hasil yang telah dicapai produk pengembangan ini, telah ditetapkan kriteria yang dapat dilihat pada tabel 2 yang di cantumkan sebagai berikut:

Tabel 2 analisis persentase (Cain, 2014; Khan, 2014)

\begin{tabular}{cc}
\hline Ketercapaian & Persentase \\
\hline Baik sekali & $81-100 \%$ \\
Baik & $61-80 \%$ \\
Cukup & $41-60 \%$ \\
Kurang & $21-40 \%$ \\
Kurang sekali & $<21 \%$ \\
\hline
\end{tabular}

\section{HASIL}

Data yang disajikan dalam bahasan ini meliputi: 1) data dari validasi ahli media, 2) data dari validasi ahli pembelajaran Kebugaran Jasmani, 3) data dari hasil ahli Modifikasi Permainan.Siswa kelas VIII SMPN 3 Panarukan. Data yang terdapat di dalam bahasan ini terdiri dari data kualitatif yang diperoleh dari sebaran angket kepada pihak yang bersangkutan.

Berdasarkan aspek penilaian dari ahli media yang berupa saran atau masukan secara keseluruhan yaitu: 1) video pembuka disampaikan oleh penyusun yang tujuannya menjelaskan maksud dan tujuan pembuatan modifikasi permainan kebugaran jasmani menggunakan video, 2) menampilkan video modifikasi permainan kebugaran jasmani secara keseluruhan, 3) judul, 4) cover, 5) greeting, 6) penayangan video permainan 1-6, 7) penjelasan cara bermain dan ukuran lapangan permaina 1-6, 8) penutup.

Berdasarkan aspek penilaian dari ahli pembelajaran kebugaran jasmani yang berupa saran atau masukan secara keseluruhan yaitu: 1) Plastik yang digunakan dalam permainan plastik balap dikemas yang lebih menarik, 2) Suara penyaji tidak jelas, 3) Pengambilan gambar penyaji jangan terlalu dekat, 4) Unsur keseimbangan belum ada, 5) Pada video permainan diberi penjelsan, 6) Dalam video permainan diberi penjelasan unsur kebugaran jasmani apa?, dan 7) Permainan sarung keseimbangan diganti.

Berdasarkan aspek penilaian dari ahli odifikasi permainan yang berupa saran atau masukan secara keseluruhan yaitu: 1) permainan plastik balap sebaiknya diberi level permainan agar medorong siswa lebih kreatif, 2) permainan ulat berlari diganti permainan lain karena tidak sesuai tujuannya, 3) permainan bola kelincahan sebaiknya menggunakan 4 jalur agar siswa lebih aktif, 4) permainan sarung keseimbangan diganti permainan lain karena keseimbangannya harusnya pada siswanyan bukan bolanya, dan 5) permainan win straight sehrusnya tidak dibuat sejajar karena jika akan membuat siswa tabrakan saat kembali ke barisan.

Di dalam proses validasi produk, tentunya diperoleh masukan dan saran dari validator produk. Berdasarkan masukan dan saran inilah tahap revisi produk dilakukan. Hal ini dilakukan untuk lebih menyempurnakan produk yang sudah valid. Adapun revisi yang dilakukan disajikan dalam tabel 3. berikut ini. 
Tabel 3 Produk Pengembangan

\begin{tabular}{|c|c|}
\hline Produk Awal & Hasil Revisi \\
\hline $\begin{array}{ll}\text { - } & \text { Judul. } \\
\text { - } & \text { Modifikasi permainan 1-6. }\end{array}$ & $\begin{array}{l}\text { Validasi ahli media: } \\
\text { - Judul. } \\
\text { - cover. } \\
\text { - pembukaan. } \\
\text { - penayangan video permainan 1-6. } \\
\text { - penjelasan cara bermain dan ukuran } \\
\text { lapangan permaina 1-6. } \\
\text { - tanyangan lambat tiap permainan. } \\
\text { - Penutup. } \\
\text { Validasi ahli pembelajaran PJOK: } \\
\text { - Plastik yang digunakan dalam } \\
\text { permainan plastik balap dikemas } \\
\text { yang lebih menarik. } \\
\text { - Suara penyaji tidak jelas. } \\
\text { - Pengambilan gambar penyaji jangan } \\
\text { terlalu dekat. } \\
\text { - Unsur keseimbangan belum ada. } \\
\text { - Pada video permainan diberi } \\
\text { penjelsan. } \\
\text { - Dalam video permainan diberi } \\
\text { penjelasan unsur kebugaran jasmani } \\
\text { apa? } \\
\text { - Permainan sarung keseimbangan } \\
\text { diganti. } \\
\text { Validasi ahli modifikasi permainan: } \\
\text { - Permainan sarung keseimbangan } \\
\text { dan ulat berlari diganti. }\end{array}$ \\
\hline
\end{tabular}

\section{PEMBAHASAN}

Tujuan penelitian dan pengembangan ini adalah untuk mengembangkan model pembelajaran kebugaran jasmani dengan modifikasi permainan pada siswa kelas VIII SMPN 3 Panarukan yang dapat dijadikan sebagai sarana pendukung guru dalam memberikan mata pelajaran kebugaran jasmani. Menurut Beuchat-Mamie, Sperisen, Molnar, \& Koçer (2018) pendidikan jasmani merupakan media untuk mendorong perkembangan keterampilan motorik, kemampuan fisik, pengetahuan penalaran, penghayatan nilai (sikap, mental, emosional, spiritual, sosial), dan pembiasaan pola hidup sehat yang bermuara untuk merangsang pertumbuhan serta perkembangan yang seimbang.

Pembelajaran pendidikan jasmani sangatlah dibutuhkan untuk mengenbangkan potensi siswa dengan melibatkan gerak fisik yaitu mengembangkan gerak fisik yg melibatkan keterampilan gerak untuk merangsang nalar dan pengetahuan siswa. Tujuan dari pendidikan jasmani, olahraga, dan kesehatan yaitu untuk, membentuk karakter yang kuat, mengembangkan keterampilan gerak seseorang, menumbuhkan kemampuan berfikir secara kritis, mengembangkan sikap sportifitas, serta pola hidup yang sehat (IOM (Institute of Medicine), 2013; Lundvall, 2015; Stott, 2013).

Model pembelajaran degan modifikasi permainan adalah alternatif untuk mendorong minat siswa dalam proses pembelajaran. Dengan modifikasi permainan siswa akan belajar dengan senang karena tidak ada peraturan yang ketat dan dalam melakukan aktivitas tidak ada paksaan. Menurut Chelladurai \& Kerwin (2017) modifikasi secara umum diartikan sebagai usaha untuk mengubah atau menyesuaikan. Namun secara khusus modifikasi adalah suatu upaya yang dilakukan untuk menciptakan dan menampilkan sesuatau yang baru, unik, dan menarik. Menurut Voss et al. (2016)kebugaran jasmani adalah kemampuan tubuh untuk melakukan sesuatu pekerjaan fisik yang dikerjakan sehari-hari tanpa menimbulkan kelelahan yang berarti. Sekolah harus 
menerapkan mata pelajaran yang sesuai dengan kompetensi inti dan kompetensi dasar yang ada dalam pengembangan kurikulun terbaru. Kemendikbud (2014) Sistem Pendidikan Nasional menyebutkan bahwa kurikulum adalah seperangkat rencana dan pengaturan mengenai tujuan, isi, dan bahan pelajaran, serta cara yang digunakan sebagai pedoman penyelenggaraan kegiatan pembelajaran untuk mencapai tujuan pendidikan tertentu.

Adapun kompetensi inti dan kompetensi dasar pada materi kebugaran jasmani kelas VIII Sekolah Menengah Pertama adalah sebagai tabel 4 berikut:

Tabel 4 Kompetensi inti dan kompetensi dasar kelas VIII (Permendikbud, 2016:3-4)

\begin{tabular}{llll}
\hline Kompetensi inti & Kompetensi dasar & \\
\hline 3. Memahami dan menerapkan & 3.5 Memahami konsep latihan \\
pengetahuan (faktual, konseptual, dan & peningkatan derajat kebugaran jasmani \\
prosedural) berdasarkan rasa ingin & yang terkait dengan keterampilan \\
tahunya tentang ilmu pengetahuan, & (kecepatan, kelincahan, keseimbangan, \\
teknologi, seni, budaya terkait fenomena & dan koordinasi) serta pengukuran \\
dan kejadian tampak mata. & hasilnya. & \\
4. Mengolah, menyaji, dan menalar & 4.5 Mempraktikkan latihan peningkatan \\
dalam ranah konkret (menggunakan, & derajat kebugaran jasmani yang terkait \\
mengurai, merangkai, memodifikasi, dan & dengan keterampilan (kecepatan, \\
membuat) dan ranah abstrak (menulis, kelincahan, keseimbangan, dan & \\
membaca, menghitung, menggambar, koordinasi) serta pengukuran hasilnya. \\
dan mengarang) sesuai dengan yang & & \\
dipelajari di sekolah dan sumber lain & & \\
yang sama dalam sudut pandang/teori. &
\end{tabular}

Berdasarkan paparan KI dan KD diatas unsur kebugaran jasmani yang wajib dipelajari oleh siswa kelas VIII adalah kecepatan, kelincahan, keseimbangan, dan koordinasi. Ke 4 unsur kebugaran jasmani tersebut terdapat dalam ke 6 modifikasi permainan yang dikembangkan. Berikut ke 4 unsur kebugaran jasmani yang terkandung dalam ke 6 modifikasi permainan yang dikembangan.

Dalam permainan plastik balap terkandung unsur kecepatan yang tampak pada saat siswa berlari menganbil plastik yang dimiliki lawan dengan secepat cepatnya, Dalam permainan bola koodinasi terkandung unsur koordinasi yang tampak pada saat siswa melakukan lepar tangkap bola sambil bergandengan. Pada gerakan tersebut siswa melakukan lempar tangkap sambil menjaga keseimbangan karena posisi mereka yang bergandengan. Permainan bola kelincahan terkandung unsur kelincahan yang tampak pada saat siswa memindahkan bola dari kardus ke lingkaran. Pada gerakan ini siswa harus bolak balik mengambil bola pada kardus dan meletakkannya pada lingkaran dengan secepat cepatnya, Permainan bola keseimbangan terkandung unsur keseimbangan yang tampak pada saat siswa melewati lintasan zig-zag dan lompat satu kaki secara bergandengan. Pada gerakan ini siswa harus menjaga keseimbangan saat melewati lintasan zigzag dan lompat satu kaki karena pada saat melewati lintasan tersebut posisi mereka bergandengan, Permainan win straight terkandung unsur kelincahan dan kecepatan yang tampak pada saat siswa berlari melewati lintasan zig-zag dan lintasan lurus.pada gerakan ini siswa harus berkelok melewati lintasan zig-zag dengan secepat cepatnya dan berlari dengan secepat cepatnya pada linasan lurus, Permainan lingkaran surga terkandung unsur kelincahan dan keseimbangan yang tampak pada saat siswa penjaga mengejar pemain dan saat pemain menuju pos dengan satu kaki.

Dalam penelitian ini menghasilkan produk berupa model pembelajaran kebugaran jasmani dengan modifikasi permaina yang dikemas dalam bentuk video pembelajaran. Produk model pembelajaran kebugaran jasmani dengan modifikasi permaina yang dikemas dalam bentuk video pembelajaran ini memiliki kelebihan yaitu mudah digunakan dan dipelajari oleh siswa, tidak hanya siswa tetapi juga guru dalam menyampaikan materi, dengan video pembelajaran dapat membantu meningkatkan pemahaman siswa pada modifikasi permainan kebugaran jasmanni yang dikembangakan.

Penelitian dan pengembangan produk model pembelajaran kebugaran jasmani dengan modifikasi permainna yang dikemas dalam bentuk video pembelajaran ini memiliki keterbatasan, antara lain: 1) subjek uji coba penelitian ini hanya 30 siswa, karena keterbatasan peneliti dalam pembuatan produk model pembelajaran 
dengan modifikasi permainan yang dikemas dalam video pembelajaran pada uji coba yang dilakukan, 2) Unsur kebugaran jasmani yang digunakan sesuai dengan KI dan KD yang telah ditentukan yaitu kecepatan, kelincahan, keseimbangan, dan koordinasi, 3) penelitian dan pengembangan ini hanya sampai pada tahap untuk mengetahui kualitas modifikasi permainan yang dikembangakan.

Berdasarkan hasil analisis data yang dilakukan peneliti dapat disimpulkan bahwa siswa sangat senang saat mengikuti pembelajaran kebugaran jasmnai dengan modifikasi permainan, serta siswa lebih antusias dalam pembelajaran dengan adanya beberapa modifikasi permainan.

\section{KESIMPULAN}

Hasil penelitian ini menyatakan bahwa produk pembelajaran kebugaran jasmani dalam bentuk modifikasi permainan dapat dijadikan sumber belajar mandiri siswa, dengan modifikasi permainan dalam pembelajaran dapat membantu meningkatkan pemahaman siswa mengenal kebugaran jasmani, Produk video pembelajaran ini nantinya akan mempermudah guru dalam menyampaikan materi kepada siswa. Berdasarkan analisis data yaitu, (1) berdasarkan hasil kajian para ahli yaitu, ahli media, ahli pembelajaran kebugaran jasmani, dan ahli modifikasi permainan tentang produk pengembangan modell pembelajaran kebugaran jasmani dengan menggunakan modifikasi permainan memiliki kesesuaian, kemenarikan, kemudahan dan kelayakan. (2) berdasarkan hasil analisis data menunjukkan bahwa siswa tertarik dan merasa mudah dalam menggunakan produk pengembangan model pembelajaran kebugaran jasmani dengan menggunakan modifikasi permainan. Hal ini terbukti pada saat siswa mengoperasikan produk, siswa lancar dan tidak mengalami kesulitan. Siswa tampak tanggap dan tidak ada yang mengajukan pertanyaan selama mengoperasikan produk berbasis angket ini.

\section{DAFTAR PUSTAKA}

Alaunyte, I., Stojceska, V., \& Plunkett, A. (2015). Iron and the female athlete: A review of dietary treatment methods for improving iron status and exercise performance. Journal of the International Society of Sports Nutrition. https://doi.org/10.1186/s12970-015-0099-2

Alawiyah, F. (2015). Kesiapan Guru dalam Implementasi Kurikulum 2013. Kajian Singkat.

Association for Physical Education. (2020). Health Position Paper. Physical Education Matters.

Bailey, R. (2013). Teaching Physical Education. In Teaching Physical Education. https://doi.org/10.4324/9781315042466

Beuchat-Mamie, S., Sperisen, N., Molnar, P., \& Koçer, S. (2018). Physical activity and cancer. Praxis. https://doi.org/10.1024/1661-8157/a003064

Cahyani. (2016). Pengembangan Model Pembelajaran Kebugaran Jasmani Dengan Metode Bermain Pada Siswa Kelas X AP 3 SMK Negeri 2 Malang. Fakultas IImu Keolahragaan: Universitas Negeri Malang.

Cain, T. (2014). The Sage handbook of action research: participative inquiry and practice. International Journal of Research \& Method in Education. https://doi.org/10.1080/1743727x.2014.937521

Chelladurai, P., \& Kerwin, S. (2017). Human Resource Management in Sport and Recreation. In Human Resource Management in Sport and Recreation. https://doi.org/10.5040/9781492596271

Coulter, M., \& Ní Chróinín, D. (2013). What is PE? Sport, Education and Society. https://doi.org/10.1080/13573322.2011.613924

Environment;, Committee on Physical Activity and Physical Education in the School Environemnt, ., \& Food and Nutrition Board; Institute of Medicine, . (2013). Physical Activity and Physical Education: Relationship to Growth, Development, and Health. Educating the Student Body: Taking Physical Activity and Physical Education to School.

Fikri, A. (2017). Meningkatkan Kebugaran Jasmani Melalui Metode Latihan Sirkuit Dalam Pembelajaran Pendidikan Jasmani Olahraga Dan Kesehatan Di SMA Negeri 1 Lubuklinggau. Jurnal Pembelajaran Olahraga. 
Gray, C., Gibbons, R., Larouche, R., Sandseter, E. B. H., Bienenstock, A., Brussoni, M., ... Tremblay, M. S. (2015). What is the relationship between outdoor time and physical activity, sedentary behaviour, and physical fitness in children? A systematic review. International Journal of Environmental Research and Public Health. https://doi.org/10.3390/ijerph120606455

Hermansah, B. (2018). Modifikasi Permainan Bola Tangan Terhadap Hasil Belajar Passing Dalam Pembelajaran Bola Tangan Mahasiswa. Jurnal Pendidikan Olahraga Dan Kesehatan, 35-41.

IOM (Institute of Medicine). (2013). Educating the Student Body: Taking Physical Activity and Physical Education to School. In National Academies Press.

Kemendikbud. (2014). Materi Pelatihan Guru Implementasi Kurikulum 2013. Badan Pengembangan Sumber Daya Manusia Pendidikan Dan Kebudayaan Dan Penjaminan Mutu Pendidikan Kementerian Pendidikan Dan Kebudayaan.

Khan, S. N. (2014). Qualitative research method - Phenomenology. Asian Social Science. https://doi.org/10.5539/ass.v10n21p298

Kurniawan, D., \& Hidayat, T. (2015). Pengaruh Modifikasi Permainan Bolavoli Terhadap Kerjasama Siswa Pada Pembelajaran Pendidikan Jasmani, Olahraga Dan Kesehatan (Studi Pada Siswa Kelas X Boga 1 SMKN 3 Probolinggo). Jurnal Pendidikan Olahraga Dan Kesehatan, 03(1), 20-24.

Kwon, E. H., \& Block, M. E. (2017). Implementing the adapted physical education E-learning program into physical education teacher education program. Research in Developmental Disabilities. https://doi.org/10.1016/j.ridd.2017.07.001

Laing, K. (2015). Constructing research questions: doing interesting research. International Journal of Research \& Method in Education. https://doi.org/10.1080/1743727x.2015.1005803

Leguina, A. (2015). A primer on partial least squares structural equation modeling (PLS-SEM). International Journal of Research \& Method in Education. https://doi.org/10.1080/1743727x.2015.1005806

Lestari, S. D. A. (2015). Penerapan Modifikasi Permainan Terhadap Hasil Belajar Passing Bawah Bolavoli (Studi Pada Siswa Kelas VIII SMP Negeri 4 Pasuruan ). Jurnal Pendidikan Olahraga Dan Kesehatan, 03, 88-95.

Lonsdale, C., Rosenkranz, R. R., Sanders, T., Peralta, L. R., Bennie, A., Jackson, B., ... Lubans, D. R. (2013). A cluster randomized controlled trial of strategies to increase adolescents' physical activity and motivation in physical education: Results of the Motivating Active Learning in Physical Education (MALP) trial. Preventive Medicine. https://doi.org/10.1016/j.ypmed.2013.09.003

López-Pastor, V. M., Kirk, D., Lorente-Catalán, E., MacPhail, A., \& Macdonald, D. (2013). Alternative assessment in physical education: A review of international literature. Sport, Education and Society. https://doi.org/10.1080/13573322.2012.713860

Lundvall, S. (2015). Physical literacy in the field of physical education - A challenge and a possibility. Journal of Sport and Health Science. https://doi.org/10.1016/j.jshs.2015.02.001

Metzler, M. (2017). Instructional Models in Physical Education. In Instructional Models in Physical Education. https://doi.org/10.4324/9781315213521

Meyer, U., Roth, R., Zahner, L., Gerber, M., Puder, J. J., Hebestreit, H., \& Kriemler, S. (2013). Contribution of physical education to overall physical activity. Scandinavian Journal of Medicine and Science in Sports. https://doi.org/10.1111/j.1600-0838.2011.01425.x

Muzakki. (2014). Pengembangan Latihan Kesegaran Jasmani Menggunakan Metode Tebak Dadu Untuk Siswa Kelas V SDN Umbul 01 Kecamatan Kedungjajang Kebupaten Lumajang. Universitas Negeri Malang: Fakultas IImu Keolahragaan.

Permendikbud. (2016). KOMPETENSI INTI DAN KOMPETENSI DASAR PENDIDIKAN JASMANI, OLAHRAGA, DAN KESEHATAN SMP/MTs. (1), 1-6.

Reza. (2013). Pengembangan Metode Pay And Game Dalam Pembelajaran Kebugaran Jasmani. Fakultas Ilmu Keolahragaan: Universitas Negeri Malang. 
Saunders, D. H., Sanderson, M., Hayes, S., Kilrane, M., Greig, C. A., Brazzelli, M., \& Mead, G. E. (2016). Physical fitness training for stroke patients. Cochrane Database of Systematic Reviews. https://doi.org/10.1002/14651858.CD003316.pub6

Schulz, J. (2013). Research methods in educational leadership and management. International Journal of Research \& Method in Education. https://doi.org/10.1080/1743727x.2012.752206

Sekaran, U., \& Bougie, R. (2014). Research Method For Business. Encyclopedia of Quality of Life and WellBeing Research.

Smith, N. J., Monnat, S. M., \& Lounsbery, M. A. F. (2015). Physical Activity in Physical Education: Are Longer Lessons Better? Journal of School Health. https://doi.org/10.1111/josh.12233

Stott, R. (2013). Physical education. Architectural Review. https://doi.org/10.4324/9781315517698-45

Taherdoost, H. (2018). Sampling Methods in Research Methodology; How to Choose a Sampling Technique for Research. SSRN Electronic Journal. https://doi.org/10.2139/ssrn.3205035

Tight, M., Symonds, P., \& Symonds, P. M. (2016). The Case Study as a Research Method. In Case Studies. https://doi.org/10.4135/9781473915480.n2

Van Hoecke, M. (2016). Methodology of Comparative Legal Research. Law and Method. https://doi.org/10.5553/rem/.000010

Voss, M. W., Weng, T. B., Burzynska, A. Z., Wong, C. N., Cooke, G. E., Clark, R., ... Kramer, A. F. (2016). Fitness, but not physical activity, is related to functional integrity of brain networks associated with aging. Neurolmage. https://doi.org/10.1016/j.neuroimage.2015.10.044 